\title{
Fra Ostgræusen.
}

Træk af Nationalitetskampen mellem Finner og Russere.

Af

F, Ohrt.

\section{I}

Det gamle Karten.

En mægtig Fremgang i materiel og aandelig Kultur har - under de vekslende politiske Kaar været det 19de Hundredaars Gave til Størstedelen af Finnernes Folk: til den Del af Folket nemlig, som fyldestgjorde to Vilkaar, luthersk Tro og finlandsk Bo. Protestantismen gav det aandelige Grundlag, og den politiske Særstilling sum Storfyrstendømmet Finland tik 1809-11, bød et vist Værn mod, hrad russisk var; hin slog Bro mod Vest, denne rejste Mur mod Øst. Men - Lutherdommen har aldrig sejret over hele Storfyrstendømmet; navnlig flere udstrakte karelske Sogne Nord

Kilder: Vørket Karjalan kirja II (1910): Dvinaforbundets Maanedsskrifter 1906-09, især Karjulan ki finsk Grænsekarelens Ugeblad Omahinen, der udkommer fr* Febr. 1910; enkelte private Meddelelser fra Finner, hvem jeg her bringer en hjærtelig Tak. 
for Ladoga, nær (trænsen, i "Stlmi Herred" og Egnen nærmest Nord for dem, er ganske overvejende græskkatolske (over 200,000 Mennesker; men fra et lidt nordligere Punkt af og helt op i Lapland er Folket luthersk

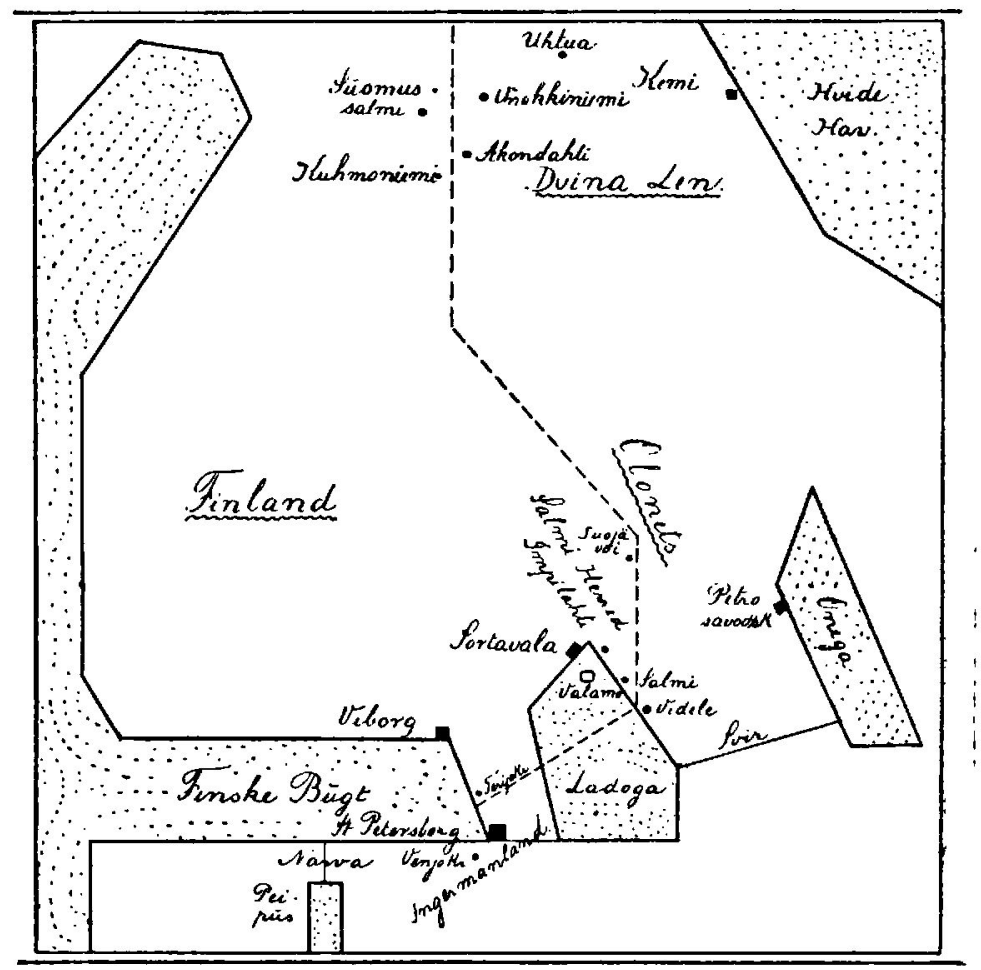

Skematisk Kort over Finland og de russiske Grænseegne.

væsentlig lige til Østgræensen.) Og endvidere: Den finske Befolkning strækker sig mod Øst og mod Syd udover Finlands politiske Grænse : Mod Øst tales karelsk $\theta$ (astinske) Mundarter $i$ et 100 à 200 Kilometer bredt 
Bælte, der langs Grænsen løber i Nord og Syd gennem det vestlige af Guvernementerne Arkangelsk ("Dvina Len ") nordligst og Olónets Syd derfor; Karelerne her, ialt vel omtrent 150,000 , naaer næsten frem til Hvidehavet og til Onegasøen. Et noget mindre Tal Karelere hor dernæst klemt inde mellem Russerne, langt inde $\mathbf{i}$ Riget, til helt hen imod Moskva (Tverkarelerne). Endelig er der Kysthefolkningen i Ingermanland Øst og Syd for Finskebngten paa begge Sider af St. Petersborg; nogle af disse Ingrere er lutherske; alle de ovrige i Rusland hwende Karelere er græske Katoliker.

Disse Russo-Kareleres Oprindelse er forskellig; nugle er Rester, som blev tilhage, dengang den finske Stamme i vor Tidsregnings første Aarhundreder gik mod Nordrest incl i det nuværende Finland; andre er omvenlt, i langt senere Tider, gaaet mod Øst over Grænsen. - For alle disse Finner - Salmiboer, russiske Karrelere "g Ingrere glipper altsaa - være sig begge eller $\operatorname{dog}$ den ene af - hine Kulturforudsætninger, den religiøse og den politiske. Her har da Nordens nyere Kultur paa denne Led fundet en dobvelt Grrænsevold, ranskelig at nverstige. Et naturligt Haab fra finsk side vilde det være at kunne skyde Kulturgrænsen frem, helst saa den dækkede den sammenhængende finske Befolknings Græuse, ot Fremstyd ogsaa til Selvværn. Der har været en kurt Tid, hvor et saadant Haab ikke syntes helt urimeligt. Men næppe havde man begyndt at tage fat, for Magthaveren mod Øst, der allerede var virksom i Forvejen, ogede Presset og foretog et frygteligt Modstød ind over baade Sprog- og Statsgrænse. Udfaldet kender intet Menneske; vort Kendskab og vor 
Sympati kan Finnernes Kamp paa Østgræusen vel i al Fald kræve. - Foreløbig ses i det folgende hort fra Ingrere og Tver-Karelere.

En Rejse fra det lutherske Finland ind i de grieskkatolske Egne kan endnu i 20de Hundredaar, i alt Fald for den ydre Sans, i visse Maader forekomme som et Spring med Lykkens Galocher langt tilbage i Middelalderen. Den gamle Tilstand er begyndt at svinde, særlig efter 1900, mindre Øst for, stærkere Vest for den ryddede Stribe i Skoven, der afmærker Rigsgrænsen. Men naar vi til Indledning vil danne os et Billed at det gamle Karelen, tager vi endnu kun ringe Hensyn til, hvor lidt og hvor meget det sidste Par Tiaar kan have ændret deri. Ved Religionsgrænsen siger vi i de fleste Tilfælde Farvel til den jævne Landevej og fortsætter ad Kærre- eller Ridestier med Kavlehroer over Moserne, eller endog ad helt smalle Gangstier, hvor saa Færdslen over Sumpone sker paa Træstammer, der til Dels hviler paa den Plet, hvor de blev faldet. og orer hvis Langside man saa balancerer frem; kun i Snefure kan her ages med Hest. Standses Stien ved Sommertid af Sø eller Elv, tyer man til nxrmeste ciaard om Baad og kan faa Lov at raabe og vinke en god stund, hris Gaarden ligger paa modsat Bred. Fra høje Bakkckamme i Skovødet eller fra Klipper i Indswerne kan der rinden skøn og vid Udsigt over det morkladne Landskal). Ensomme Udflyttergaarde kan paatræffes; oftest er dog Befolkningen samlet i storre Landsbyer; de ligger gerne paa en Bakkekam og tiest ved de storre fiskerige Soer. Korn kan dyrkes helt op i Dvina Karelen. En lille Labyrint af Tofter og Stængegærder kan omgive Husene; 
i Olonets er der Plads for Kvæget i et halvt underjordisk Rum under Bo-stuerne. Det hænder Øst for Grænsen, at indtil syv gifte Søskende, eller nære Frænder, med Familier bor i taard sammen under den gamle Faders Styre. Udenfor Landsbyen, ogsaa hvis den ikke er Kirkeby, ligger en Fyrrelund, hror de Døde hviler og modtager Gravofre; ofte er der et lille Bedehus ved Lunden.

Hvor Sult eller Smitsot ikke har hærjet for længe, er Østkarelernes Folk en vakker, rank og kraftig Slægt; i sjælelige Egenskaber vel en Overgangsform mellem Russisk og Finsk, mindre indesluttet og tungsindet end de vestligere Finuer, men gennemgaaende ogsaa regnet for mindre paalidelig i Ord og Handel end de; paa den anden Side sædeligt stræeng, sejere til Arbejile end Russerne, næppe saa larmende og aabenmundet som de. En russisk Bonde, der bler spurgt, hvorfor han og hans Byfæller helst tog sig Hustruer fra den karelske Naboby, srarede: De sludrer ikke saa megret som vore Kvinder. Et særlig godt Lov ogsaa for Stothed og Arlighed synes Dvinakarelerne at fortjene. Om Olonetserne lyder russiske Domme saare forskelligt; Straffeprocenten i Olonets skal kun være halvt saa stor som Ruslands gennemsnitlige.

Øst for Grænsen er Jagt, Fiske og det ringe og gammeldags Jordbrug ikke nok til Folkets Livsophold. Især fra Dvina Len gaar om Efteraaret en Strom af Bissekræmmere ind over Grænsen og strejfer med deres Kramvarer vidt omkring blandt Finlands Almue. Det er denne livlige, glade Type som Runeberg har skildret uforligneligt i „Elgskyttarue“. Saadanne Familiefædre 
er sj: + liln hjemme, somme kun en Uges Tid hvert 2det, 3dic Aar. Navnlig af Olonetsere drives dog ogsaa Handel i storre Stil; for en stor Del gaar Petershorgs Laderhandel gennem Karelere, af hvilke nogle har tjent store Furmuler. Men Folkets Hovedmasse er yderst fattiı. Skorene i russisk Karelen tilhører overvejende Staten, "or Bondejorden ejes her (ikke i finsk Karelen) af Kommunen (paa russisk Vis), og som i Fortidens lanmark kan den enkelte Bonde have sine Jordstrimler spreilt fia mange steder. I en Del af Olonets omfordיlis der hvert 12te Aar, saadan at den enkelte kommer af med. livad han selv har nydyrket; Systemet virker ganske litmmende paa al Energi. Indtil nyeste Tid har dut gammoldags stredjebrug med Afbrending af Skor og Saaning i Asken været herskende. Uaar og Vilddyr sitult Krirusyge gor stor Fortræed. Ulv og Bjorn jages merl Busir eller stundom endnu ned Spyd og Økse; i tinkl Karclen har dog Almuen, der her mest ejer Jorden (Wr. ndlejet Jagten til sportsherrer, oftest Udlændinge. - I Olonrts (r der endelig nngen Bjærgværksdrift, i Solumde warmmer sig Jarnmalm, karelsk Porfyr smykker Isakakirkrns Indre og Napoleon I's Hvilerum i Invalideintellet.

l'('n wrakk-katolske Gudstjeneste holdes fra gammel Til fila Kirkeslavisk; Øst for Grænsen har man ikke vincet valnt til, at Præsterne kender synderligt til Sognehornenes Sprog. Forskellige Sekter, især de ,gammeltroendes", har indtil nyeste Tid været meget udbredte heroppe. Hele Nordruslands afsides Bygder har Ry som Kætterreder; højere Form for Gudstro har Sekterne her dog gennemgaaende næppe bragt. - Religionens 
Ceremonier gennemsyrer hos de fleste vel nok meget af Livet; Korstegnet gøres utallige Gange; Fasten er haard, især de gammeltroendes; Helgenerne staar paa Hylde eller hænger paa Væg; det hænder, at en Skuespillerindes Billed klippes ud af et russisk illustreret Blad og i god Tro æres som Gudsmoder. Fra flere Egne, i al Fald i Dvina Len, hedder det imidlertid, at Folket ikke komner i Kirke; snart skyldes det vel Kætteri, snart maaske Ligegyldighed eller Uvilje. De gamle, rigt udformede Bryllupsskikke og -sange har i og for sig lidet med Kirken at gøre; ved Gravfærd er det Grædekvinderne med de enstonige, gribende Klager. som giver Højtiden dens aandelige Præg, og de kan i den ene Linie synge om Adamsparadiset, $i$ den næste om Dødsrigets bjæffende Hunde.

Baade saadanne Kvảd og Yttringer af Alnuesfolk kan bryde igennem Billed- og Helgen-Udenværkerne og røbe Tillid til Skaberen eller Tro paa, at Hjwrtelaget er Hovedsagen. Men megen gammel Overtro er gængs. Syge Børn bades i visse Egne i hellige Søer, og deres Klædningsstykker efterlades til "Søens Herre" (Hat, hvis Hovedet, Sko, hvis Benet var sygt). $-O g$ dog har der ret længe, selv i russisk Karelen, fra Myndighedernes Side været gjort noget for Folkeoplysning. Den ældre Slægt plejer ikke, heller ikke i det finske Salmi Herred, at kunne læse og skrive. Men siden 1870erne har der været russisk-sproglige Skoler i hver større Landsby, helt oppe i Dvina Len. Og Resultaterne? Det siges, at efter 4 Aars Skolegang har Barnet lært Regning med hele Tal, samt Kunsten at oplæse og atskrive russiske Ord, ikke den at fatte Bøgernes Ind- 
hold, og af Lærerens Tale forstaas kun de aller simpleste Ting (de færreste Lærere evner vel at faa noget ud ai den i og for sig hypermoderne Metode). Selv om somme vel nok lærer mere, glider det vel oftest af igen (bortset fra dem, der som Soldater eller ad anden Vej faar tilegnet sig noget Russisk); og talende er det, at fra russisk Karelens Folk i de sidste 30 Aar ialt kun to unge Mænd har søgt til Seminarier for selv at blive Lærere. Med alt dette gør Folket ubetinget et kvikt, lærenemt Indtryk. - Paa finsk side kipmper russiske og finske Skoler om Overtag.

Oplysningens lave Trin kan være skæbnesvangert for Sundhedstilstanden. Ikke alle Husraad er saa uskarlelige som Ofret til Vandaanden. 1909 rasede Kopperne i Salmi Herred; man vilde sine Steder ikke lade sig vakcinere, men i den Syges Hus samledes Naboerne on et Bord med Gildemad og ovede en formelig Dyrkelse af Patienten, der selv sad for Bordenden og repræsenterede "Herrens Straffedom". Saalænge Sygdommen varede, maatte Smuds ikke sættes i Bevægelse, Tøj eller. Bohave altsaa ikke vaskes, ellers blev Aanden vred. Til Trolde og Hekse tyer man fremfor til Lager, paa hvilke der nu heller ikke er Overflod. I Uhtna (Dvina Len) var 1907 een Læge - ukyndig i Finsk -, hvis Kreds omfattede 5 Sogne paa ialt 20,000 Mennesker; i Vuokkiniemi Sogn noget vestligere hærjede Tyfus for kort siden paa fjerde Aar. Det store folkerige Salmi Sogn i Finland har endnu 1910 ingen Læge.

Underligt maa det være for en kultiveret Nutidsfinne at komme ud til disse Landsmænd i Øst. En Christian Flor eller en Koch i det endnu sovende Sønder- 
jylland stod ikke overfor saadanne Svælg, som skiller den latherske Finne fra den store Mængde af græsktroende Karelere. - Heller ikke Fortidsminderne lyder idelt Lys. Der er Blod mellem Brodrene. Gang paa Gang i tidligere Hundredaar har Karelere, etter russisk Ordre eller af egen Drift, hærjet grumt i Finland, og Finlæendere har efter Evne gjort Gengæld. Dog mangler ikke fredelig, aandelig Paavirkning fra svunden Tid; Folkesange er fra Estland og Vestfinland i Mængde naiet helt up til Dvina Len, hvor de har taget markelige Former'; Opskrifterne herfra er formet til Finlands Nationalepos (Kalevala), der omplantet i den hjemlige Jord har virket stærkt til Fremme for en national Kultur. Russisk Karelen fik herved i litterært dannede Finners (ojne en 'Tid endog et vist romantisk Skær som Sangenes Land - et Land, man dog gærne lod blive $\mathrm{i}$ det taagede Fjerme, indtil vort slægtled er gaaet over til grundigere Interesse for disse Egnes Kaar. For Aartier siden havde nationalt vaagne Finner da ogsaa fullt up at gøre med at vakke og oplyse deres egne Trosfaller; og et relativt stærkt Finsk-Finland matte vare Ostkarelernes naturlige Frembjelpere; for en svensk Overklasse vilde Opgaven ligget fjernere. Men desuden er der et Rusland, som hjærtensgæxne selv paatager sig ait nødvendigt Kulturarbejde $i$ disse Egne. 


\section{II.}

\section{Et "ungt" Larmlen.}

Overfor Russerne foler disse Karelere sig selvfolgeligr som en forskellig Folkestamme. Og Hjemkarlighed til deres eget fattige Land kender de meget rel til. ..Her i vort Karelen“" kan en Almnesmand sige mrd Kitrtegn i Stemmen. Men uverfor Finland og dets Kultur?

Naar Talen hiver om nationale Muligheder, staar Salmiber, Drinamend og Olonetsere ikke som en forshrlslus Masse. Lavest kommer Olonets, hvor Tegnene til folkelig Opvaagne'n har viret meget svage; her synu's dit Mugthaverens Chancer aller sikrest. Salmifolkene har det vigtige yule Vilkaar at ho indenfor Stortyrstendommet Finland, saa Finsk ng Russisk kæmforr om Folket under nogenlunde lige Kaar. Det fjerne Ivina Len endelig har to Fortrin, Sprogets og - Ran-elens. Dvinamundarten staar „Rigsfinskens“ Ord- og Lyilforluli naxl. Fjernere ar her Salmi-Olonets stillet; sitrlig over disse to Landskaher er gennem Aarhundreder livlger skyllet ind tra det russiske Nahosprog (naturligvis an samkremmets, ikke ad litterær Tej) og har paavirkut Ordforraal, Ordfrining, Lydforhold (mange stemte Lyd); for Salmis Tedkommende har dog det politiske Sambrr med Finland (og i senere Aar Folkeskolerne) giort Bogsproget godt kendt; men for Honetsboerne er det ikke wden ridere tilgn'ngeligt. - Men desuden ndger Lvina Lens lanselbarere, Bissekræmmerne, et vigtigt Bindeled mrllem Vestens Kultur og deres Hjemstavn. Vnder de lange Ophold i Finland faar mange af dem ell Folelse af Samhu, faar Øjet op for at her er noget 
at lære, som Hjemmet savner. Allerede ved Aar 1880 bragte nogle Kræmmere en pietistisk (Læstadiansk) Iver med sig hjem; skont Bevægelsen i og for sig var rent. religiøs, vakte den en Del Lyst til at lære Lxesekunsten. (for Opbyggelsesbøgernes Skyld) og at faa fiusk Kristendomsundervisning i private Skoler (ogsaa i Finland e1 Pietismen, demokratisk i sit Vasen, kommen til at virkt nationalt fremmende for Finskheden). Regeringen greh snart ind med Fængslinger; men ved 1890 vaagneds Roret op paany; Uhtua, ret langt mod $\emptyset$ st, tik endos en finsk Lejebogsamling (for et Aar var gaact, tog dor Politiet Bøgern('); ja 1898 truffer ri en finsk Folkeskole, den første Srale, $i$ en lille By nær den tinske Grænse; dens Levetid blev ikke længere end Bibliotekt't. - Især i de sidste 15 Aars Tid har ikke faa unge karelske hræmmere i Finland liert sig at lase; de har bragt finske Bager og Aviser med hjem, ofte ogsaa en finsk Hustru, og siden fik deres Burn lært at lese Finsk. Og de, som tilsidst tog varigt $\mathrm{B}_{0}$ i Finland og stundom naaede Velstand, har plejet at holde Forbindelsen med Hjemmet trofast vedlige, og $i$ de senere Aar at virke for dets Delagtiggwrelse i finsk Kultur. - Unægteli har man ogsaa kunnet se enkelte Kræmmere gaa Magthavernes Erinde: i 1899 ndbreltes, ikke helt ulten sliges Medvirken, det Rygte blandt Finlands Landalmut. at den russiske Regering paatankte store .Torduddelinger til de fattige, blot de vilde vende sig fra de hjemligs Agitatorer. Sine Steder blev det troet; men om den store sociale Omvæltning hørtes siden intet. Derimor gik de enkeltes Forræderi ud over Dvinakræmmernes store Flertal, idet mange Finner en Tid lang mistæenkte. 
tem alle for at gaa russisk झrinde og jog dem af Huse.

Imidlertid hændte snart andre, mægtige Ting: Rusland kom under den store Krigs og de indre Oprors Tegn, og det tik sin Duma; Zaren tilsikrede ved Manifest af 1905 sine Undersaatter Tros-, Presse- og Forsamlingsfrihed, $n g$ i Finland gryede under Storstrejkens dodsspandte Stilhed nogle lyse Aar for Storfyrstenrimmmet.

Da slog helt oppe i Ivrina Len Luftningerne fra Ost og fra Vest sammen. En kraftig bevidst Folelse af at være finsk Folk skød sig frem, ng tillige brød det ny rusistie Foreningsliv til social og politisk Udviklings Fremme sirr Tej hertil. $O g$ ad af selve Dvinafollets Midtr skabte den hevægede Tid Folkeforere, forrest vel den ganske unge Jeremejeff-Räihi, der en kort Tid havde boet i Finland, men nogle Aar for var flyttet tilbage. Det konstitutionelt-demokratiske Partis Afdeling for den store Landsly Chitua lagde for. Man holdt en Række Folkemoder omkring Nytaar 1906 og udkastede et omfattende Progrum: Kronens .Jord bor blive Privateje, Kroneskovene resentlig overtages af Kommunerne, der skal latgges ordentlige Veje mellem Landsbyerne og oprettes Postforhindelse med Finland, Vandre- og Folkeskuler med Undervisning paa Finsk bor grundes, Gudstjenesten skal holdes paa Mlodersmaalet, Emluedsmændene wor magte Folkets Sprog. Ved Valgmandsvalgene, der holdtes i Marts i Staden Kemi ved Hvidehavet, mødte Masser af Karelere np. De to russiske Dumamedlemmer fik siden til Fremlæggelse en Adresse, der præciserede Tarelernes Ønsker; den havde 3000 Underskrifter. - 
Som med et Slag lagde det sig altsaa for Dayen, at Dvinakarelerne var ved at vaagne som Finner og siom russiske Statsborgere.

Selvfølgelig maatte alt dette vække den sturste, Opmærksomhed paa tinsk Side (trænsell. I April 190); samledes dvinakarelske Kobmend, bosatte i Finland, til et Møde i Vasa; her vedtoges at stifte en Forening paa finsk Grund. $O g$ saa holdtes endelig i Tummer. fors (August) et Todagesstavilc; til Stede Far Dvinakarelere (baade indrandrede og fra Rusland tilrejste; en enkelt Ingrer var med) samt Finlandere. Her stiftedes Dvina Kurelens Forlund med disse Formaal: Skoler og Bogsamlinger i Dvina Len, Fremme af dets Naringsveje, især Agerbrng og Kvægavl. Gaar Selskabet ind, skal dets Midler tilfalde Helsingfors' Universitet, som er pligtigt at nytte dem i samme Aand, f. Eks. til Russokareleres Uddannelse ved finske Litresieder.

Vilkaar for et gunstigt Arl,ejde kunde synes skalit. Endnu 1907 lod der sig holde en glad Sommerfest oppe i Uhtua, - saa mange Mennesker rar aldrig for set sammenstarnede i Drina Len. Der var ogsaa finske Studenter med hvide Huer og Lyreemblem; man stirrede med megen Undren og Respekt paa disse og tog deres Bærere for Underofticerer; Forklaringen „det er Studenter" maatte atter udtydes dem sum: Folk, der kan læse og skrive og mere til.

Kun altfor snart lod dog Ruslands Regering høre fra sig; næppe mange kyndige Folk havde vel ogsaa turdet haabe en ustyrret Udvikling paa Zarlufternes Grundlag. Omkring ved Nytaar 1908 lagde den tunge Haand sig fastere end før over Landet. Forbud, Tilsyn, 
Forvisninger kom. Det konstitutionelle Partis og Dvinakarelerforbundets Virksomhed er blevet ganske umuliggjort. $O g$ det forlyder, at Folket deroppe tilsyneladende er ved at synke ned i slov Ligegyldighed. Haabet, hos dem der trods alt haaber, maa nøjes med at drage Varsel af det Lys, som thammede op hin korte Tid mellem Nytaar 1906 og 1908, og som viste, at Dvina Len kunde fostre finske Handlingens Mænd.

Efter 1908 er Stillingen da den, at Vest for Grænsen, i Salmi Herred, kappes Finner og Russere stadig om at vinde Terrain, men Østen for har Russerne Arbejdsmarken - Drina Len og Olonets - alene. Frygt for, at der skulde foreligge "storfinske" Planer om politisk Forening med Russokarelerne, kan vel ingen aandeligt normal Russer nære; men naturligvis vilde det styrke Finskheden, om disse Halvanden Hundredtusind blev nationalt vundne, og svække den, om de vandtes afgørende for russisk Kultur. Kultur er ogsaa Løsenet fra russisk Side: Ikke blot ved Trusler og Trang og ved Afspærring fra Finland søger Regeringen at slaa det ny Liv ned, men Kirke og Skole skal gøre alle Nordvestguvernementernes Born til sande russiske Miend og Kvinder. Vi gaar over til at se, hvorledes Finner saa vel som Russere paa de enkelte Kulturomraader, Næringsliv, men især Kirke og Oplysning, i de seneste Aar har arbejdet i de omstridte Egne.

III

Nceringsliv.

Enkeltmands eller Kommunes Overtagelse af Statsjorder og -skove, samt Lettelse af Samfærdslen, var 
Karelers Ønsker Øst for Grænsen, udtrykt ogsaa i det store Dvinalénsprogram af 1906 , der tilføjede: bedre Forbindelse med Finland. Kun lidet af disse Ønsker er blevet opfyldt. En Lov af stor Rækkevidde, men redrorencle et andet Forhold, er givet Nov. 1906: Hvert Bylagsmedlem kan af Kommunens Jord kræve for sig selr til prirat Eje et Stykke .Jord efter sin Families MedIemstal (eventuelt kan han ogsaa kobe Jord derudover). Hermed tilsigtes altsaa det gamle Fællesskabs Ophævelse. I hvilken Udstrækning dette $i$ de to Karelerguvernementer er traadt ud i Livet, kan jeg desværre intet sige om. - Hvad Statens er, sidder derimod godt fast. I Olnuets foretog Staten 1910 ny Jordfordeling, højst ngunstig for Folket; selv hævdede den Ejet af næsten al Skov, sua man frygter for snart at skulle købe sit Byggetimmer af Regeringen. - En Lysside ved Olonets' Forhold er dets Semstno-institution (Art Landdag). I de senere Aar skal ogsaa her som andetsteds denne have gjort sig fortjent af Samfundet paa disse Omraader. Man har gjort Skridt for at faa Folket bort fra det gamle Sverjelırug og skyede end ikke at indkalde en finsk Agronom, der tillige fik lagt forste Grund til Mnsekultur og til Mejerivirke; ogsaa finsk Kvæg er indført. - Dvina Len har ingen Semstvo, Guvernøren er enemægtig. Her er Svedjebrænding nu bleven forJadt; men Agerbruget spiller heroppe kun en ringe Rolle.

Fra Olonets klages over de fleste Varers Dyrhed; Varerne skal købes og hidskaffes fra de fjerne Købstæder østligere i Guvernementet. Indtil 1906 hentede man ganske rolig en Række Livsfornødenheder, saaledes Mel og Salt, billigt fra Finland, uden om det yderst 
svage Toldeftersyn. (Til Finland udføres især Fisk og Fuglevildt). Men siden er Tilsynet blevet strængere; Soldater er sendt op, har holdt Huseftersyn hos Kobmænd og Bonder og konfiskeret Masser af ulovlige Varer; man skal nu tvinges til at købe Ostfra. Et staar fast: Fattigdom og Nød var 1910 usæedvanlig stor i Olonets som i Dvina Len. Foruden Kræmmerne strejfer nu Skarer af Tiggere, ogsaa Kvinder der ovre fra, om i Finland. Om Uaar har været medvirkende til den akute Elendighed, véd jeg ikke.

Samfierdselsmidlerne i russisk Karelen ligger det i Regeringens Plan at udvikle, vel at mærke saaledes, at Linierne skal knytte til mod Øst og Syd, ikke mod Vest, i al Fald ikke til luthersk Finland. Telegraf helt op til den halvkarelske Købstad Kemi ved Hvidehavet er der allerede, og der paatænkes en Jærnbane derop (gennem Ost-Olonets). Køreveje og Postruter mellem Landsbyerne skal ogsaa øges, men ingen gaa over Græensen til luthersk Finland. „Dvina Karelens Forbund" havde faaet sat en Smule i Gang, ladet bygge 1000 Farne Vej indenfor et stort Kirkesogn, Vuokkiniemi i Dvina Len, men maa ikke fortsætte. I over 10 Aar har der været en privat Postforbindelse (tilsidst ugentlig) mellem nævnte By og Suomussalmi i Finland; mange Penge, som Kræmmere sendte til Hjemmet, gik ad denne sikre Vej; Brevhemmeligheden brød Postbud Lesonen, der $\mathrm{i}$ al denne Tid gik den 24 Mil lange Vej, heller ikke; han kunde selv ikke læse. Ruten er nu bleven forbudt, vel nærmest i Frygt for Tilførsel af finske Aviser. Og mellem de lidt sydligere, store Nabogrænsesogne Akonlahti (russisk Side) og Kuhmo (finsk) 
er stadig Fodstien og den slanke Fyrrestamme over: Mosen eneste Sommervej. Paa et Sted undervejs, hvor Stier krydsedes, saae Meddeleren 1906 en tilglattet Pind naglet paa et Træ, med finsk Paaskrift i latinsle Bogstaver: Til Akonlahti Kirke; i Kirkebyen spurgte man med Stolthed, om jeg lagde Mærke til den Vejviser de havde ladet sætte op. Pinden var Stoltheden værd; den sad der som Symbol paa Russokarelernes Trang til at vise Finlands Kultur Vej ind $\mathbf{i}$ den vildsomme Ødemark. Ruslands Regering vil derimod, at vejlost Skov-øde skal danne en kinesisk Mur for at skærme Riget imod Vest.

Lysere bliver Nutidsbilledet, naar vi kommer til Salmi Herred i Finland. I tidligere Tid har Bonderne her haft onde Kaar, store Adels- (og Kloster-) Godser ("Donationslande") har bredt sig, og Bonderne blev halvfri Fæstere, indtil den finske Stat 1867-90 efterhaanden kobte Donationsjorden, som saa Bønderne de fleste Steder har tilkobt sig billigt af Staten. - Et Mærkeaar for selve Jordbruget blev 1880, da Autti Kuksonen nedsatte sig paa Jalovaara og her lagde for med moderne Mønsterdrift; endnu mere dog 1894, da "Østkarelens Landbrugsselskab" (statsunderstottet) stiftedes; det har bl. a. bragt det gamle Svedjebrug stærkt ud af Kurs og indrettet vellykkede Udstillinger. Østkarelen har nu flere vandrende Landbrugsskoler og Konsulenter. En Mand, der har gjort sig højlig fortjent. af Østkarelen i materielle som aandelige Ting, er den nys afdøde Historiker Dr. Hainari (før Forsstrøm); han har saaledes virket til at skaffe Bønderne Skov, i sin Tid ulovlig bortsolgt, tilbage, og fremhjulpet Oprettelse 
af Komninnekasser (Suojärvi har en Fælleskasse paa 1 Million finske Mark), der tilvejebragtes især gennem gunstige, med Staten som Mellemmand foretagne Tommersalg; Renterne kommer ogsaa de jordlose i Kommunen til gode, idet de delvis gaar til Folkeskoler, Læger, Veje, Broer. Vejnettet udvides nu stadig.

I de senere Aar, efter at Bonderne var udfriede fra Godsejervieldet, har moderne Virksomheder som Savværker og Papirfabrikker begyndt at true de nylig dannede smaa Selvejergaarde ved fristende Salgsvilkaar. Fragtkørsel med usikre Udsigter til hoj Fortjeneste har fra gammel Tid lokket Befolkningen; de Sagkyndige raader den til at blive ved det solidere Jordbrug og Krægavlen. F'or ganske nylig er Staten begyndt at skaffe de helt jordlose billig Adgang til Jord, idet den til Udstykning forelobig har købt 1000 Hektarer.

En Jærnbane fra Sortavala Købstad ved Ladoga mod Nordøst op til Suojürvi nær Grænsen er paa Tale, men kommer næppe foreløbig. Den skulde bl. a. drage Nytte af de vældige, indloringende Skove ved Suojärvi og af det nære Olonets' Fiskeeksport.

\section{IV \\ Kirken.}

Frihedsmanifestets Ord var klare. Hvad for havde været utænkeligt, var nu tilladt: Udtræden af den hellige, rettroende Kirke, den som indtil da havde været en Fold, hvis Dør kun kunde aabnes udefra, et Indelukke, som ene den kom ud af, der banlyst og fortabt slængtes bort over Hegnet. Om de græsktroende Karelere virkelig i Mængde følte sig dragne af den lutherske 
F. Ohrt.

Kirke og traadte over til den, vilde dermed én af Skillemurene mellem dem og deres vestlige Brødre vare falden, og de vilde med disse sidste faa Del i det store Nationalitetsværn, som ogsaa Polakkerne ejer i den kirkelige Afstand fra Magthaveren. Ikke at tale om, at mian havde vundet ny religiøse Værdier, og taget Afsked med den Kirkeaand, der hos den store Mængde vel nok snarere har tremmet slovt Taalmod under de engang girne Kaar, og hos sine ivrigste Børn ekstatisk Stirren efter det evige Lys, end just Trang til at bedre, hvad i denne Verden bedres kan. Trosskifter i større Tal har ogsaa nok fundet Sted, særlig i nogle kirkeligt blandede Sogne vestligere i Finland, men i Salmi Herred næppe synderlig mange, og kun $i$ et ganske ringe Tal (om overhovedet?) i russisk Karelen -- Drina Len ikke undtaget trods det mærkelige pietistiske Røre nogle Aar tilbage. $O g$ fra finsk luthersk Side har man formodentlig gennemgaaende vist forsigtig Tilbageholdenhed, ogsaa overfur Salmi Herred. Dog fandt Politimyndighederne 1909 en Del finske Ny Testamenter i Akonlahti i Dvina Len (de var kommet ind over den nære finske Grænse) og brændte de ubehagelige Bøger. $O g$ samme Aar fængsledes 4 finske Metodister, der holdt Møder og sang aandelige Sange rundt i russisk Karelen; de førtes til Arkangel, men frigaves straks. I 1910 er ingen Missionærer gaaet over Grænsen til Akonlahti. - Desuden holder de russiske Myndigheder helst Menigmand i Uvidenhed om de ret simple Formaliteter, der er at iagttage ved Udtræden af Kirken. For Tiden ligger der næppe Overdrivelse $i$ at sige: Trosfrihed er Øst for Grænsen et tomt Ord. 
Selv om nu disse Karelere forbliver $\mathrm{i}$ deres gamle Kirke, saa har jo Dvinafolkets Optræden vist, at Trang til god Oplysning paa Modersmaalet kan forliges hermed, og lykkeligvis kan det samme paavises for manges Vedkommende i Salmi Herred. Regeringen har set Farerne, og der sættes nu et ret stærkt Arbejde ind paa at vinde Folket for Rusland netop gennem Kirke og Præster. Man har svunget sig op til en hel Indre Missionsgærning blandt Karelerne.

Snart efter Trosmanifestets Komme frygtede den hellige Synode i Petersborg (Ruslands overste Kirkestyre) for ondt Nyt fra Karelen og sendte foreløbig en Kommission af Embedsmænd, Præster og Munke til Olonets under Viborgarkebispen Sergius' Ledelse. Kommissionen kunde give ret beroligende Meldinger. Til at kæmpe mod Lutherdom og Finsklied stiftede den imillertid "Karelens ortodokse Broderskal" for Olonets under den hellige Martyr Georgs Værn (1907). Man besluttede at uddele Biller (eller dog Bibelstykker) og andre hellige Boger, trykte paa Liygi (Østkarelsk) med russiske Bogstaver, ikke paa Rigsfinsk. (Mattæuserangelict foreligger paa Karelsk, Trerkarelsk, allerede fra 1820). En af Kommissionens Gejstlige holdt i en Landsby en retledende Tale til Bonderne og eksaminerede saa bagefter en Tilhorer: Hvad Forskel finder nu Du paa den russiske og den fremmede Tro? Paa daarligt Russisk fik Bonden formet sit ejendommelige Srar: "Herre, Sagen ligger ikke i Troen, men hos os selv; naar vi selv bliver gode, saa bliver ogsaa vor Tro bedre." - Et tilsvarende Broderskab (rettere en Udgrening af det samme?) grundedes omtrent samtidigt for finsk Salmi 
Herred som Modvægt mod det her siden 1880ne bestaaende "Sergius' og Hermans Broderskab", der havde tilladt sig at udbrede Opbyggelsesboger paa Finsk. Det ny Samlag har dog siden brugt sine Penge op og er gaaet halvvejs istaa. Lederne har da tilrevet sig det gamle med dets Midler efter at have faact dets hidtidige Leder fjemet; den nuværende Formand for begge Broderskaber er Kyprian. 1908 er der stiftet et Mikaclsbroderskab for Dvina Len. En Side af disse Foreningers Virke synes at vare: Kontrol med Sognepræsterne.

Det galder for Staten om at have mange og paalidelige Proster i disse Egne. Fuld af Iver for Karelernes religiose Liv har Regeringen ladet bygre en Mangde ny Kirker i Olonets (der siges 18 i 1907-09). Den hellige synode har for nylig vedtaget at forhoje Prastelonmen i ca. 60 Sogne $i$ de to turernementer, dng kun for de Praster, som forstaar Folkets Sprog. Prasteseminariet i Petrosavodsk (Olonets' Hovedstad ved Onega) har 1909) endug genindfort Lindervisning i Karelsk, der var ophievet 1872. - Paa finsk Nide (Salmi Herred) er sket grememgribende .Endringer, men i 'll noget anden Retuing. Her var indtil 1899 de rettroende Praster nesten blevne som hjemmestedte; de drev ingen Russerpolitik, men (*udstjenesten loldt de ganske vist paa Kirkeslavisk, og Folkets ganle finske For- og slagtsnavne lnd de vige for finere og helligere russiske (omtrent tilsvarende som svenskdannede Præster i sin Tid i Testfinland). Den tidligere Viborg-Erkelisp Antonius (nu Petersborgs Metropolit) stillede sig venligt overfor Finskheden; den nuvarende, Sergius, lod i Forstningen til at ville trade $i$ samme Spor; han opfordrede 
endog til finsk Gudstjeneste i Salmi Herred; men i de senere Aar har han fundet det rigtigt ganske at slaa om. Præsteskabet er i Løbet af faa Aar nuesten blevet helt fornyet; "nu kaster Erkebispen os snart hid, snart did, som naar unan sparker til Svampe i Skoven", lyder en Ytring af en Præst. $O g$ med Flertallet af de ny Sjælehyrder har det sig underligt, som Regel kan de kun hojst ufuldkomment, undertiden slet ikke Finsk; deres Almendannelse kan staa yderst lavt, Kortspil er alt for ofte en kær 'Tidkort; og sommes Opfattelse af deres Fimbedes Art er ret egen. For nogen Tid siden opfordrede en Folkeskolelærer paa Mantshinsaari sin Præst til at holde en Andagt ved Aarsundervisningens Begyudelse; han kom og talte, men var meget urolig for at faa den tilberlige Lon for Umagen, indtil Lareren gav ham to Rubler af sine egue fattige Midler. Klager, f. Eks. fra Sortavala Kolistad, over Præster, der ikke uden Tolk kunde tale med Sognebornene, har ikke nyttet. Kun ved enkelte Fester prakes der nu, hvor Præsterne evner det, paa Finsk eller Karelsk. -- Der er dog de Miend indenfor Finlands grask-katolske Gejstlighed, som med Engstelse ser paa den ny Kurs, som mishilliger Religionens Indordning under politiske Formaal og ser en moralsk Fare i, at Folket staar fremmed overfor sine Praster netop i en ranskelig Overgangstid, hror gammel skik brydes med ny Kultur. Hvilken Mangel paa Visdom synes det ngsaa at ville vinde en Betolkning gennem saadanne Præster, og hvilken Inkonsekrens, naar man tanker paa, hvorledes Karelsk i Kirken delvis protegeres Ost for Gronsen? Er man bange for, inden for Finland at give Modersmaalet for meget, 
eller er Sagen ikke snarere den, at politisk paalidelige Præster har man foreløbig ikke ment at kunne faa tilstrækkeligt Tal af nden at ty ogsa til Personer, der kun kan Russisk? Det synes ogsaa, som om den Mand, der nok er den egentlige Sjæl i Arbejdet, nemlig ovennævnte Kyprian, egentlig godt indser Modersmaalets religiøse Værd.

Kyprian er en Degneson fra Novgorodegnen $0 \mathrm{~g}$ født 1879. Har han allerede fra Barnsben kendt til Karelsk? Der bor en Del Karelere ogsaa i dette Guveruement. Som Præstemunk blev han fra 1906 udsendt af Erkebisp Sergius sammen med nugle andre, især Diakonmunken $I s a k$, for at drive Mission. Missionsgudstjenesten er delvis holdt paa Liygikarelsk. Bønner læses, Sange synges, de ti Bud forklares og indskærpes. Der har gennemgaaende værec stor Tilstromning og Andagt; Isak siger $i$ en Beretning de Ord: „Hvor megen barnlig Tro og hvor mange Taknemmeligheds-Taarer findes der dog her (i Olonets); det kommer af, at Folket forste Gang hører Gudstjeneste og Prædiken paa sit eget Sprog." Endda skal særlig Isaks Karelsk være et underligt Bryg af Russisk og Finsk; ovre i Salmi Herred, hvor enhver vilde forstaa ham, hvis han talte Rigsfinsk, vækker det Smil og Kritik. Kyprian er nu steget til Arkimandrit (Abbed) og, som vi véd, Hoved for de karelske Broderskaber; rygtevis hedder det, at Sergius skal forflyttes og den 31-aarige Kyprian stige til Frkebisp. - Klosterliv er et Led i hans Planer. En Del unge Piger fra Salmi har han formaaet til at forlade deres Hjem og drage den lange Vej til Nonneklostret Krasnostok ved den polske Grænse; Tanken 
er, at en Del af dem siden skal grunde et Datterkloster i Karelen. Tre af disse Jomfrner er døde dernede; flere rørte gennem Bønner og Taarer („Vi græd, saa vi var ved at blive til Vand", siger én) Mrunken Isak, der harde ledsaget dem did, til at tage dem med sig tilbage igen.

Et dyrebart Middel til at knytte Karelerne i Kærlighed til Moderkirken ser Kyprian og Sergius i Fester og Valfarter. Og den xldgamle Rede langt nde i Ladogas Hav, Øen Valamo med sit Kloster, har her faaet stor Betydning; ogsaa ellers regner Finnerne den for en af Russervæsenets Herreburge i Karelen. Skoleungdom i Mængde sendes derover og taar Øjne og Øren fyldt. Sommeren 1909 bragte en særlig stor, „ambulant" Helgenfest. Et af Klostrene paa det græske Athos havde skænket Helgenbilleder til Karelens Broderskab, Salmi Kirke skulde have en Maria, Kolatselkä Kapel i Vest-Olonets en Panteleimon Martyr. Undervejs tog Billederne ind paa Valamo, hvis Kloster skal være grundet af Athosmunke; her var første Fest; Voksne og Born fra Østkarelen stævnedes over til Valfart, men Tilslutningen blev dog her nok ikke efter Forventning. Des mere kom der ud af Helgenernes Indtog i Salmi By, hvor 5000 Mennesker skal være mødt, og siden af Martyrens Komme til Kolatselkä. Kyprian talte paa Karelsk og formanede til at vogte sig for dem, der kommer i Faareklæder, men indvendig er røverske Ulve. Der har været Jordbund for hans Ord. Trods alt kan religiøs Cfordragelighed og Uvilje mod Kætterne og hvad deres er findes hos mange ogsaa i Salmi Herred. 


\section{$\mathrm{V}$ \\ Ungdom og Oplysnixı.}

I Salmi Herred, paa finsk Grund, har Finnerne jo længe haft Frihed til at grunde Skoler; men forst sent er der taget fat; indtil ned i 1880ne fandtes her kun enkelte finske Vandreskoler, samt fra ca. 1850 et Par russiske faste Skoler, grundede af Godsejere i Donationslandene. Men 1880 var der grundet et Lærerseminarium i Sortavala; hertil knyttedes 1887 et Vandrelæreseminarium, der snart blev godt søgt af Græske-Katoliker. Fra nu af tog man ivrigt fat baade med Vandreskoler (Elementarundervisning for mindre Børn) og med faste Folkeskoler (for de lidt ældre, den første 1886). I Ro kunde der virkes indtil Bobrikotfs Tid. Han naaede i 3 Aar at faa grundet 10 russiske Folkeskoler, hroraf 8 i det sydøstlige Græensesogn Salmi; og han kiævede nogen Undervisning $\mathrm{i}$ og paa Russisk, selv i de finste Vandreskoler i (træensekarelen. Storstrejken 1905 gav en kort Tid Luft, den af Bobrikoff indsatte Kuntrollor ("Skoleinspektør") Lebedeff blev jaget bort, og et Konvent af davarende russiske Prister indstillede endog, (1907) at dor i de finske Barneskoler slet ikke skulde undervises i eller paa Russisk, til (rengreld burde der sine Steder indrettes særlige hursus (for de lidt ældre) i Russisk - en ønskelig Ting, indrømmer enhver i denne (rrænseegn, hvor man altid har Nytte af at kende Nalosproget; Aikebisp Sergius og Tiborg Konsistorium stadfæxtede virkelig Forslaget. Ikke des mindre har man tvunget Russisk igennem i Vandreskolerne i hele tre Sugne.

Og $\mathrm{i}$ de aller sidste Aar spændes Kræfterne fra begge Sider; Skole paa Skole, snart en finsk, smart en 
russisk, indvies. Tallet paa Skoler i den før saa forsømte Egn er blevet relativt højt efter finske Forhold. - Elementarskolerne her er mest "vandrende" (inden for Byer i ett Sogn; de faste af dem er væsentlig grundede paa privat Yppe); de er oftest kirkelige, saa Præsten kan faa Vandrelæreren afsat, hvis han forsømmer "Rigssproget" eller viser finsk Sindelag. De finste Folkeskoler (for storre Born) staar derimod under Stat og Kommune. De russiske Folkeskoler holdes oftest af Rigets Skoleministerium (med Dumahjælp), enkelte af

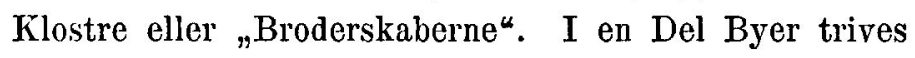
finske og russiske Skoler jærnsides; saadanne Steder kan Stemningen mellem Parterne (baade hos Voksne og Børn) være yderst fjendsk. Man gor megct for at de finske Skoler skal blive tomme; de russiske Elever faar stedvis Mad, Sko og Løfte om gode Pladser i Petersborg; og somme Folk har ladet sig skræmme til at tage deres Born ud af finsk Skole ved Rygter om, at nu skulde Forældrene privat lonne dens Lærer, samt paa Omgang fyre i og rense ad i Lokalet. - Den af Finnerne afholdte "Skoleinspektor" Sadornikoff har Erkelisp og Generalguvernør for nylig tvangsforflyttet (som Præst) ind i Rusland. $-O g$ nu selve Undervisningren i Russerskolerne? Metoden er den for omtalte: Finsk banlyst som Hjælpemiddel; flere skoleinspektorer, ja Miend i Rigets Skoleministerium har ganske fordomt den, og dog fastholdes den; lignende Famlen som i det kirkelige: af lutter Skræk for det finske Sprogs Magt hindrer man det russiske den letteste Tej frem. Megen Væut læggres derimod paa Indøvelsen af Kirkerangen, her naaes ret vidt, og Børnenes Interesse vækkes. 
Indtil det sidste Aar har Russerne haft det særlig afset paa Grænsesognet Salmi ved Ladoga (samt Øen Mantshinsaari udfor). I Salmi er nu flere russiske Skoler end finske (1910 vistnok $12 \bmod 11$ ), men rigtignok tilsammen flest Elever i de finske. Generalguvernør Seyn, der iøvrigt er Lutheraner, har i Sommer gastet én Kystby i Sognet; han telegraferede derefter til Kejseren, at det rettroende Finsk-Karelens Befolkning overalt (!) havde udtalt sit brændende Ønske om at komme i Forbindelse med Ruslands Folk, og at den bad om endnu flere russiske Skoler. Men i den samme Landsby, hvor Excellencen tog Stikprøve paa Folkets Russerlængsel, fejredes i Oktober (som rundt om i Finland) Hundredaarsfest for Cygnæus, den finske Folkeskoles store Grundlægger; 400 Børn fra Salmi Sogn var til Stede. - Efter at Russerne nu har bidt sig forholdsvis godt fast i Salmi Sogn, synes de i den allersidste Tid at ville kaste sig over det nordligere, udstrakte Grænsesogn Suojärvi. Stykke for Stykke vil man søge at vinde frem og tilsidst sætte Kronen paa Værket i denne Landsdel ved at russificere Sortavala Stad.

Sortavala og Omegn er Stedet for de højere finske Undervisningssæder i Grænsekarelen. Foruden Seminarierne har Kobstaden en Latinskole. - Og lidt ostligere, i det lutherske Impilahti Sogn, nær Religionsgrænsen, er for omtrent 3 Aar siden grundet en Højskole. Mange advarede og fandt det for tidligt med slig Undervisning i Egne, hvor den lavere Skole endnu var saa ung; men. en tillidsfuld Kreds hævdede, det var vel et Forsøg værd at drage ogsaa unge grasktroende Mænd og Kvinder 
til Højskole; vandtes de for finsk Kultur, vilde de om faa Aar ogsaa blive Børneskolesagens trofaste Støtter i deres Hjemstavn, medens derimod Børn, der fra Folkeskolen siden kom under de gammeldags Forhold, vanskeligere vilde kunne bevare det nedlagte Frø spiredygtigt. Foruden lutherske Elever har da ogsaa græsktroende fra Grænseegnene meldt sig; dog er Tallet paa de sidstnæunte foreløbig ikke i Stigen, men 3-4 Aar er for kort Tid at drage Spaadom af. - I den senere Tid er der endelig rundt i Landsbyer dannet Ungdomsforeninger, der vil bringe de unge god Oplysning og sund Tidkort. Og der kan trænges til, at nogen vil tage sig af den unge Slægt $i$ disse Aar. En Landeplage, før lidet kendt i finsk Grænsekarelen, har begyndt at hærje nhyggeligt, det er Brændevinen.

Endnu $\$ 894$ kunde en saa udmærket Kender af Salmi Herred som Dr. Hainari i sin Bog „Billeder fra Grænsekarelen" give Folket det Lov at være ædrueligt; kun paa Helgenfesterne („Prasniekat") kendtes til Fuldskab. I de sidste Aar er dette ved at forandre sig. Over Grænsen fra Rusland "smugles" nu Brændevin ind i stor Stil, Flasker i hundredtusindvis; Smuglerkøbmænd har slaaet sig sammen i store Flokke og fører Varen ganske aabenlyst ind; viser Toldmændene sig (der er 8, fordelt paa 3 Landsbyer), skyder man paa dem; en Toldvagt blev for nylig dræbt. Og ad Søvejen gaar det endnu glattere; ved Ladogas Nordstrand har hidtil ingen Toldskibe været. Det er dog nu vedtaget at for*ge Toldvagten, og der vil formentlig komme Toldmotorbaade i Søen. - Under Alkoholens Tegn udarter Folkets gamle Yndlingsfester, Helgenmindedagene, mer og mer; 
det religiøse giver ikke Festen Præg; i Rus og Skrig og Slagsmaal lober det hele ud; halvvoksne Drenge sætter en Ere i at optræde- drukne, helst i Følge med Piger. Mord og Roverier tiltager i Østkarelen. Flere Steder sygner ogsaa Ungdomsforeningerne hen. - Der er dog enkelte steder nu holdt Møder af Befolkningen for at faa Helgenfesterne begrænset eller ophæret; Alattu Kommune har saaledes forbudt "Legestævne" paa Mikaelsfesten sidste November. Andet Godt forlyder fra Øen Mantshinsaari; her raser de Gamle, og: Ungdommen tager sig bedre Ting for. Da Erkebispen kom og holdt Gudstjeneste, drak de ældre sig fulde, mens Ungdonsforeningen samme Aften holdt et velgastet Inde. - Tegn staar da mod Tegn i Grænsekarelen. De Finner, der ser lysest paa dette Landskabs Fremtid, hævder som deres Indtryk, at Russersind og Had til Vestens Kultur mest findes hos den ældre Slægt, medens Ungdommen, efter at finske Folkeskoler nu i over 20 Aar har virket her, synes at give gode Lofter. Maatte det vise sig, at de spaar ret!

I Drina Len naaede man fra 1906 at faa grundet nogle enkelte finske Barneskuler; fra Alajürvi By fortaltes med stor Glæde, at efter blot halvanden Maaneds Sommerskole havde mange Børn lært at stave, og megen Læselyst var vakt. Ogsaa enkelte Bogsamlinger og Læsestuer kom til. Med haard Haand har Russerne slauet ned. De ny Foretagender blev forbudt. To ledende Dvinakarelere, ovennævnte Jeremejeff-Räihä og Remsujeff, blev fængslede, ført til Kemi og siden forvist til Kirgisernes Land (Øst for Ural) paa to Aar ; førstnævnte døde her af Lungesvaghed, ca. 25 Aar gammel. Remsujeff, 
der er kommen tilbage 1909, har vakkert og gribende skildret Begyndelsen af sit Fangeliv. - Nu oges de russiske Skolers Tal; om faa Aar vil der være mindst én $\mathrm{i}$ hver eneste By. Landvæsen og Haundgerning skal optages blandt Skolefagene. Selv om de opslaaede Brød maaske ikke alle bliver rigtig bagt, er det et Spørgsmaal, om den finske Hjemmekultur (ikke det finske Sprog) heroppe vil være stærk nok til at hævde sig. $\mathrm{Og} \mathbf{i}$ de sidste Aar er det næppe let for unge Drinakarelere at tage paa finske Højskoler. Myndighedernes Skræk for Smitten fra Vest er saa stor, at det nu ogsaa er forbudt finske Videnskabsmænd at færdes $\mathrm{i}$ de to russisk-karelske Len paa Forskerrejser.

Med stor ydre Kraftudfoldelse har den russiske Skolesag gjort Fremskridt i Olonets, især da fra 1907. De faa finske Vandreskoler, der var begyndt, blev fejet væk. Et ekstraordinært Guvernementsmøde krævede ved denne Tid energisk Regeringens Hjælp til ny Skoler "med Henblik paa den overhaandtagne finske Agitation i Egnene ved den finske Grænse". Og Regeringen var villig. Det gammeldags olonets er nu én af de faa Egne i hele Rusland, hvor det Tal af Skoler, den almindelige Skoleplan kræver i Forhold til Indbyggertallet, er naaet! Det tyder stærkt hen paa, at Oplysning alene ikke er Maalet heroppe. En Lærer siger allerede 1904 i "Olon. gubern. vjædomosti" rent ud, at der $\mathbf{i}$ hans Sogn er to Skoler "til Sprogets Udryddelse og med det samme til Undervisning i Bønner, Kristendomsgrundlag, Skrivning og Regning“". Skolerne er dels

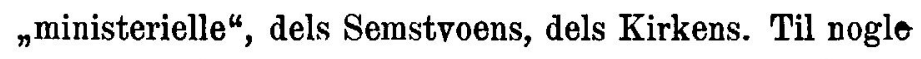
er knyttet Natherberg for de fjernestboende og Spise- 
hase for de fattigste. Nogle Skoler giver tillige Undervisning i Hnstlid og Haandværk. De færreste Lærere kender det karelske Sprog; det er strængt forbudt Eleverne at svare Læreren paa Karelsk, ja at tale det indbyrdes indenfor Skolens Grund. Alle Elever kommer i Kirke hver Helligdag og deltager i Sangen. Der arrangeres ogsaa „Skolerejser" o: Pilgrimsfarter under en Lærers Ledelse til hellige Klostre, hror man spiser sammen med Munkene og tilbeder den undergørende Helgen.

Allerede for flere Aar siden er man kommen ind paa at arrangere fædrelandske Fester for unge og gamle. 1908 fejredes saaledes Mindefest for Petersborgs Grundlæggelse; i Videle Skole f. Eks. bød Festprogrammet forst paa liturgisk Gudstjeneste, hoortil Skoleungdommen var udkommanderet, om Aftenen Foredrag om Hovedstaden med Lyslilleder, „Fædrelandssange“ af Eleverne, Orkesterstykker og Nationalhymnen i Grammofon. I ca. 10 Aar har man virket ved oplysende Foredrag, sted vis endog 3 Gange maanedlig; de trækker udmærket Hus, naar der er Lyshilleder. De fleste Tilhørere er Unge, der gaar eller har gaaet i Skole og fatter noget Russisk, men ogsaa ældre gaar hen; i de mere afsides Byer er det hændet, at Billedforklaringerne tillige gaves paa Karelsk, hvilket vakte stor Glæde.

Retssproget, der i Salmi Herred er Finsk, er Øst for Grænsen naturligvis Russisk. De indstævnede taler Karelsk, en Tolk oversætter, „og Gud fri os for slige Oversættelser : En vigtig Oplysning lades uænset, Sagen kommer i et helt andet Lys" (meddelt i Olon. gub. vjæd. af en russisk Almuelærer, der selv har lært sig Karelsk). 
Det er fra Olonets, Brændevinen strommer til finsk Karelen. Vi tør da ikke fornd gøre os høje Tanker om Edruelighedens Stade i dette Guvernement. Et Par Træk: Kort før Jul 1908 hængte en (ræstgivers 30aarige Son sig under et Deliriumsanfald; nogle Dage efter drak hans 20-aarige Broder sig ihjel. Omtrent santidig domte Retten en Bonde, der havde dræbt sin Søn, til halvandet Aars Fængsel; Straffen blev saa mild, fordi Morderen (og den myrdede) i Drabsøjeblikket havde været drukne. Om Regeringen vilde installere hver ny Skole $i$ en samtidig nedlagt Kro, gjorde den en stor Gærning. Men Brændevinen er Regeringsmonopol; Salget gav 1908 for hele Olonets (den russisktalende Del medregnet ialt ca. 400,000 Mennesker) over 1 Million Rubler i Renindtægt. 1901-05 var Salget i Nedgang; siden er det steget. - Dvinakarelens stotte Folk har til de aller sidste Aar staaet i Ry for sin Edruelighed; man har ikke taget mod de tilbudte Kroer; endnu 1910 hedder det, at der i den karelske Del af Dvina Len foruden i Kemi kun findes 1 Kro, nær Hvidehavet. Hvorvidt der desuagtet nu trives privat Salg, kan jeg ikke sige; i al Fald kommer der russisk Brændevin til det finske Nabosogn Kuhmoniemi.

\section{VI}

De som dor, og de som ril leve.

Vi bør ikke glemme at give Ruslands øvrige Karelere nogle faa Ord. Særlig i 17de Hundredaar er Skarer af Græsktruende vandret bort fra de kætterske Svenskes Rige, langt mod Sydøst til Egne, der dengang af Krige og Pest var næsten affolkede. I sin Tid har Karelere 
naaet helt ned Sydøst for Moskva. De fleste Steder er Sproget nu vist helt uddedt, Landsbynavne som Kareli staar til et Minde. Men i Guvernementerne Tier og Nongorod tales endnu Karelsk vel af henced 100,000 Mennesker (1897 ca. 130,000). Deres nationale Undergang er vis, ingen Finne drømmer om at hindre den. Indreruslands Karelere er paa alle Sider omgivne af Russere; disse har ogsaa kilet sig ind imellem dem (Moskva-Petersborgbanen gaar delvis gennem karelske Egne). Deres Kaar er efter russisk Maal ret gode. Ved Indvandringen kom de til al Lykke mest under Kronen, ikke under Adelen. Der er nu temmelig mange Skuler. Præsterne synes at have levet sig langt bedre ind i Folket og lært dens Sprog end f. Eks. i Olonets. Stedvis er over Hælvten af Sogneboerne læsekyndig. Jo mere Velstand og Oplysning stiger, des mere dor det karelske Sprog. Drukkenskab er jøvrigt ret udbredt.

Ingermanlands aldste finske Befolkning, Voterne, er nu en lille Rest paa 2-3000 Mennesker. Men siden er mange Karelere ( $\mathrm{g}$ Savolaksere) kommet til, først grasktroende (Inkerikot), siden (mest i 17 de Hundredaar, da Landet var svensk) lutherske. De bor langs Finskebugtens Runding, mod Nordvest op til Finlands Grænse, mod Sydvest til Narvafloden. Petersborg ligger jo paa gammel finsk Folkegrund; Øst for Hovedstaden er der endnu stadig finske Landsbyer.

Medens de græsktroende Ingrere (Voter og Inkerikot) efterhaanden uhjælpelig russificeres gennem Kirke og Skole, hævder de lutherske, der ejer Religionsmodsætningens uvurderlige Gode, vedvarende og bevidst deres finske Nationalitet. Deres Tal er vel ialt ca. 
115,000. Finsk Gudstjeneste har de altid haft. Efter at Skolevæsenet er bleven ordnet, har Rusland taget noget Hensyn til Lutheranerne. Et Privatseminarium i Kolppana uddanner lutherske Lærere af finsk Nationalitet (de undervises paa Russisk); disse kan søge til lutherske Folkeskoler, hvor ganske vist Undervisningen skal gives paa Russisk, undtagen dog i Religion. 25 Sogne har tilsammen ca. 125 saadanne Skoler; det store Venjoki Sogn nær Sydvest for Petersborg har endog 13. - I andre Kommuner tages derimod kun Russere til Lærere. Ved disse "russiske" Skoler underviser saa en "vandrende" finsk Seminarist paa Modersmaalet i Religion, f. Eks. ved 5 Skoler i alt. I Grænsesugnet mod Finland, Valkeasaari, Bane- og Toldstation, er der slet ingen finske Skoler; her og $\mathrm{i}$ det nordlige Nabosogn gives derimod ved de russiske Skoler af ambulante Finner nogle finske Sprogtimer foruden Religionsundervisningen.

Desuden har de lutherske Ingrere rent finske Søndagsskoler samt Laanebiblioteker. Og finske Landbrugsselskaber, Andelsforetagender og Afholdsforeninger er i de senere Aar vokset frem.

\section{VII.}

Det lutherske Finland.

Kampen mellem russisk og finsk Sprog og Kultur staar ikke blot i de græsktroende Kareleres og i Ingrernes Lande. En Egn i selve det lutherske Finland er for Tiden ved at trues alvorligt. Det er Storfyrstendømmets Sydøstflig ned mod Ingermanland. Sydkarelen (Viborgegnen) er ellers et vaagent Land; Folkebibliotekernes Tal er baade absolut og relativt det storste i Finland, 
og i Retning af Skolesøgningen staar man i første Række. Men Banen V'iborg-Petersborg paa "Karelske Tange“ (ca. 3 Timers Fart) er ved at ændre sit nærmeste Opland ogsaa Vest for Grænsen. I Jærnbanens Nærhed gaar Jorden i urovækkende Grad over paa russiske Hæender. Skylden lagges delvis paa finske Penge- og Forretningsmænd, der opkoler Bondejord for derpaa at udstykke den til velhavende Petersborgere. For disse er Egnen nemlig et saare yndet Sommeropholdssted, og den ene, ofte pragtfulde, Villaby skyder op efter den anden. Men ogsaa det faste russiske Folkeelement tager Tækst. Russiske Smaahandlere er haarde Konkurrenter for de finske; og de fredsommelige russiske Arbejdere foretrakkes for de finske Socialister med deres hyppige Strejker. - Der er nu Planer oppe om et helt Jirnbanenet ud fra St. Petersborg helt op til Vuoksenfloden og Ladoga. Og der er ingen Tvivl om, at Russerne her som i Salmi Herred er til Sinds at hage sig fast Stykke for Stykke stadig længer mod Vest - hvad enten det nu skal hlive til Alvor med hele Viborg Lens Indlemmelse i Riget eller ikke. 1911 er det 100 Aar siden disse Egne bler genforenede med det ovrige Finland.

Og dette ovrige Finland? Altid staar der Trusel over hele Landet, aldrig dog saa stærkt som nu. Dumaens Rigslovgivningslov af 1910 inddrager bl. a. Rigssprogets Brug i Finland, de dær boende Russeres Rettigheder $\mathrm{g}$ til en vis Grad Undervisningsplanerne under Dumaens og Rigsraadets Myndighed. Den finske Landdag af Sept. $1910 \mathrm{fik}$,til at udtale sig om“ forelagt bl. a. Ordningen af Storfyrstendømmets Russeres Ligeret med Finnerne (Den afviste dette som alt det andet 
forelagte, stemplende Dumaloven af 1910 som blottet for lovlig Gyldighed for Finland). Vel er det Meningen, at de eventuelle russiske Embedsmænd i Finland skal kende Landssprogene; foreløbig skal man i to Petersborgske Gymnasier være begyndt faknltativt at undervise i Finsk og Svensk. Men den nationale Fare er klar nok. Det finske Folks i Forhold til Magthaveren langt højere Kulturniveau, dets Kærlighed til Hjemsproget, det kirkelige Svælg mellem de to Parter, dette og mere giver Tryghed for, at om den finske Nations Undergang vil der ikke blive Tale. Alle Kræfter vil blive spændt og vil holde ud.

Der kan siges: Men alt $\mathrm{i}$ alt, hvilken Tillagegang, hvilken Nedstemning af Forventninger i de faa Aar fra Storstrejken 1905 til Statskuppet 1910! Forst et opblussende Haab om at vakke Brødrene Øst for Grænsen til nationalt Liv; snart slaas det ned, og Kampen (bortset fra Ingrerne) føres kun paa Storfyrstendømmets Grund; to Hjørner af Landet, Nord og Syd om Ladoga, trues haardt, og saa tilsidst Cdsigt til at se den Fremmede staa midt i Landet, brede sig i dets Embeder, kolonisere hist og her. Man kan sige dette; men der bør føjes til: Næppe mange vaagne, finsksindede Mænd og Kvinder har i disse Aar taget Haab for Tished, de har ikke glemt, at de byggede i Dalen ved en Vulkan. Var Tiden blid, tog man fat, hvor man kunde; ingen Mulighed var det tilladt at forsømme. Blev Dagene onde, forbavsedes man ikke, blev heller ikke modlos, men har taget Kaarene op, som de byder sig nu. Og her, som overalt, opøvede selve Arbejdet ny Kraft hos alle dem, der var med. 